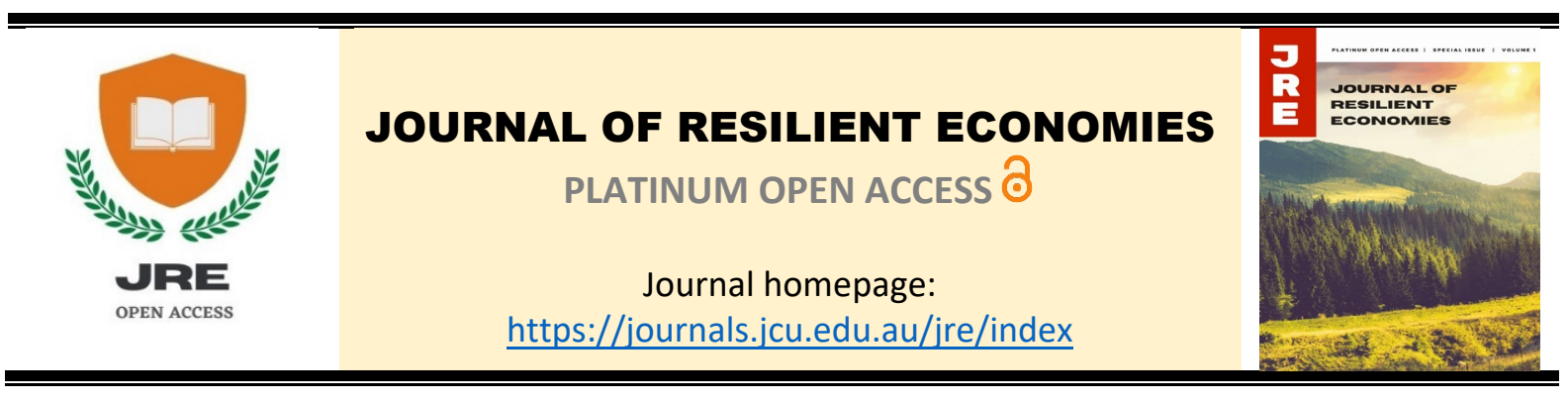

\title{
The role of servant leadership and resilience in predicting work engagement
}

\author{
Endro Puspo Wiroko
}

email: endro.puspowiroko@univpancasila.ac.id

Faculty of Psychology, Universitas Pancasila, Indonesia

https://orcid.org/0000-0001-9686-4177

\section{Abstract}

Improving work engagement among Indonesian banking employees has become crucial in today's economic situation due to the Covid pandemic. This study aimed to examine the predicting effect of perceived supervisor's servant leadership and individual workplace resilience on work engagement. This research used a quantitative cross-sectional approach. Snowball sampling method was employed to collect research data via an online survey that targeted 87 employees of various banks in Indonesia. The measures used in this study were the 9-item Utrecht Work Engagement Scale, 6-item short form Servant Leadership Behaviour Scale, and 21-item Resilience at Work Scale. Multiple linear regression analysis showed that servant leadership and resilience simultaneously had a significant influence on bank employees' work engagement $(\mathrm{F}=14.762 ; \mathrm{p}<0.005)$ with a contribution of $26 \%\left(\mathrm{R}^{2}=0.260\right)$. When given separately, resilience contributed $8.9 \%\left(\mathrm{R}^{2}=0.089\right)$ whereas servant leadership contributed $25.8 \%\left(\mathrm{R}^{2}=0.258\right)$ to work engagement. This study concluded that the supervisors' servant leadership is an important factor in complementing employees' resilience in gaining work engagement.

Keywords: Resilience, Servant Leadership, Work Engagement, Job Demands- Resources model, Multiple Regression

Journal of Resilient Economies (JRE) publishes original research with a multidisciplinary focus to further advance the important concept of resilience. JRE is fully supported by James Cook University Open Journal Systems (OJS), driven by the belief that knowledge has the power to change lives, and that research outputs should be freely accessible online, without barriers. To cite, include:Author(s), Title, Journal of Resilient Eonomies, volume, issue, year, pages and DOI.

DOI: https://10.25120/jre.1.1.2021.3821 


\section{Introduction}

Work engagement can promote the excellence of an organisation's ability to achieve its mission, an important matter that is required in present economic challenges (Hoole \& Bonnema, 2015). Studies have proven that work engagement is associated with better task performance (Christian, Garza, \& Slaughter, 2011; Lichtenthaler \& Fischbach, 2019). Therefore, more researchers are keen on investigating work engagement and its predictors (Bailey et al., 2017).

As the main driving force of Indonesia's finance sector, the banking sector contributes the most to the country's Gross Domestic Product (Hutauruk, 2020). The banking sector supports Indonesia's consumption, investment, and international trade. Moreover, the banking sector is needed to boost the performance of businesses during this current Covid-19 pandemic. It can support businesses by restructuring credit or deliver new types of credit to consumers. Another challenge faced by the banking sector is to maintain credit quality to avoid granting nonperforming loans. Looking at this condition, banking employees need to possess such a positive attitude while working. Accordingly, the work engagement in the banking sector has not been proportionally highlighted. In fact, work engagement could be an important factor in supporting banking employees' target achievement. Thus, the Indonesian banking sector was chosen as a research setting for this study.

Bakker (2011) explained two main factors influencing work engagement: personal resources and job resources. Personal resources focus more on factors within individuals, whereas job resources refer to contextual factors external to individuals that can support goal attainment, lessen job demands, and trigger individual advancement (Bakker, Demerouti \& Sanz-Vergel, 2014). Therefore, following Schaufeli \& Bakker (2010), both job and personal resources could improve work engagement. In this study, the author chooses servant leadership as job resources and resilience as personal resources.

Leadership has been recommended as an essential organisational factor for keeping employees engaged and generating thriving organisations (Luthans, 2002), especially servant leadership. Greenleaf $(1977 ; 7)$ asserted that "The servant-leader begins with the natural feeling that one wants to serve, to serve first, then to lead". Servant leaders offer guidance and stimulating duties for their team members (Chiniara \& Bentein, 2016) while providing emotional reassurance, the ability to understand the feelings of another, resources, and positive evaluation. Conventional leadership styles use a top-down managerial perspective to nourish work engagement. Servant treat subordinates as intelligent and self-reliant individuals by putting them first. Therefore, this type of leadership goes out of a leader-centric focus.

As an adaptive capacity that furnishes organisational resilience, employee resilience is understood as a set of learning, networking, and adaptive behaviours (Kuntz, Näswall, \& Malinen, 2016). Resilient behaviours are represented by support-seeking, management response to a crisis, collaboration, and constant performance development. Employee resilience in this study is examined as a behavioural construct rather than a trait or an attitude.

Resilience is frequently explained as a personal characteristic that verifies adjustment to hardship and is studied using health outcome indicators (e.g. mental health, well-being) or using variables related to a trait (e.g. hardiness, optimism) (Robertson et al., 2015). Looking at the increasing attention toward organisational resilience, especially behaviours in which employees are able to build a resilient organisation (Nilakant et al., 2016), latter scholarship has sought to comprehend how individual resilience is demonstrated in the work setting and to distinguish resilience from its well-being and dispositional correlates (Southwick et al., 2014).

Previous studies have proven a positive relationship between servant leadership and work engagement (e.g. Kaltiainen \& Hakanen (2020), Kaya \& Karatepe (2020). There is also a positive relationship between resilience and work engagement (e.g. Waddel (2015)). It is important to investigate servant leadership as a job resource and resilience as a personal resource to predict work engagement. This study is among the first studies examining the combined effects of servant leadership and resilience in predicting work engagement to the best of the author's knowledge. This study proposes an interesting concept that job and personal resources act together to influence work engagement $-\mathrm{a}$ thought that is still scarce in the current literature (Bakker \& Albrecht, 2018). Therefore, the general aim of this study is to examine the joint effects of servant leadership and resilience in predicting work engagement. Specifically, the author seeks to determine are servant leadership and resilience good predictors of work engagement?

\section{Literature Review}

\section{Work engagement}

Work engagement is explained as a cognitiveaffective positive state that links employees to their duties having the considerable skill to achieve their target. This infatuation is powerful gradually and not only centred on certain substances, situations or behaviour (Salanova, Schaufeli, Llorens, Peiro, \& Grau, 2000). Early engagement researcher Kahn (1990) brings up an "engaged state" that people carry out their responsibilities by experiencing great eagerness. Eventually, some authors started to develop burnout phenomena as the counterpart of work engagement (Leiter \& Maslach, 2003). On the contrary, Salanova et al. (2000) suggest that work engagement is an autonomous variable, and it is not just the antithesis of burnout in a continuum variable. 
The latter theoretical point of view explains that work engagement is shaped by three dimensions: vigour, dedication, and absorption (Schaufeli, Bakker, \& Salanova, 2006). Vigour refers to a deep desire to carry out activities with elevated mental resilience and energy. Dedication is about creating meaning to work and perceiving work as an inspirational, enthusiastic, and pleasant activity. Absorption is characterised by happiness while working and elevated attentiveness (Salanova et al., 2000; Schaufeli, Salanova, González-Romá, \& Bakker, 2002).

\section{Servant Leadership}

According to Spears (1995), Greenleaf derived the term servant leadership in the 1970 essay, The Servant as Leader. Indeed, Greenleaf "inspired the servant leadership concept among modern organisational theorists" (Russell, 2001, p. 78). For Greenleaf, servant leadership "begins with the natural feeling that one wants to serve, to serve first. Eventually conscious option guides one to aspire to lead. That person is intensely different from one who is leader first" (Greenleaf, 1977, p. 13). Spears (1995) extend Greenleaf's (1977) work and distilled from Greenleaf's writings ten attributes that define servant leadership: (a) empathy, (b) listening, (c) healing, (d) consciousness, (e) persuasion, (f) conceptualisation, (g) anticipation, (h) stewardship, (i) commitment to the growth of people, and (j) building community.

A study of servant leadership and employee commitment to a supervisor showed that the servant leadership approach is different from other leadership styles in terms of its prominence on how leaders support their followers (Sokoll, 2014). Followers of servant leaders are authorised by uncommon freedom to bring their competencies into effective action. They also exhibit a considerable level of trust in their servant leaders. Servant leaders grow connections in which followers are supported to improve service. Servanthood depicts a leadership model that teaches an understanding of selfgiving without self-glorification (Carroll \& Patterson, 2014).

Putting the interests of the served before their own is also a quality of servant leaders. They show better social responsibility and accentuate more on team members' growth and interests (Parris, 2013). Therefore, servant leadership has a more moral tone that ascertains it from most other models: the servant leader is mainly concerned with the followers' development.

The essential part of servant leadership theory is the leader's interest in the followers' welfare and continuous development (Laub, 2018). The critical proposition is that servant leaders are fundamentally moved by altruism and caring for the community, and so servant leaders convey genuine responsibility for the subordinates (Hoch et al., 2018). Servant leaders dedicate to justify development by showing appreciation, giving evaluation, allowing most encouraging challenges, and optimising followers' accountability (van Dierendonck, 2011).

Servant leadership is found to be correlated with more engaged employees by many studies (Eva et al., 2019; Hoch et al., 2018). Servant leadership implementations can boost employees' adaptive and task performance particularly through work engagement (Kaltiainen \& Hakanen, 2020). Kaya and Karatepe (2020) also revealed the immediate supervisor's servant leadership positively correlate with higher employee work engagement.

\section{Employee's Resilience}

The concept of resilience has been examined in various populations such as students (Reyes et al., 2015), law enforcement (Arnetz, Nevedal, Lumley, Backman, \& Lublin, 2009), immigrants (Samuels, 2015), and caregivers (Saria et al., 2017). Resilience has also been examined together with other concepts such as psychological growth and acculturation (Yu, Liu, \& Yue, 2017), recidivism (Fougere, Daffern, \& Thomas, 2015), trauma (Bonanno, 2004), forgiveness (Broyles, 2005), and spirituality (Williams, 2017). More distinct terms such as emotional resilience, educational resilience, and behavioural resilience have developed because of the investigation of resilience in many disciplines. Moreover, the definition of employee's resilience has evolved due to practitioners and authors' increasing attention (Bardoel et al., 2014).

The term employee resilience was developed to target individuals in the workplace (Näswall et al., 2013) due to the study of resilience in mixed subjects such as psychology, psychiatry, neuroscience, sociology, genetics, endocrinology, and epigenetics (Herrman et al., 2011). Defined as "the capacity of employees, supported and facilitated by the organisation, to utilise resources to positively cope, adapt and thrive in response to changing work circumstances" (Näswall et al., 2013, p. 3), employee resilience "will affect one's reaction to workplace experiences, such that those "with more resiliency' will be better prepared for the challenges everpresent in today's workplaces" (McLarnon \& Rothstein, 2013, p. 63).

Winwood et al. (2013) discerned seven elements of employee resilience while developing their Resilienceat-Work (R@W) instrument. Those elements included (a) living real, (b) finding calling, (c) nurturing point of view, (d) controlling tension, (e) work alongside cooperatively, (f) develop professional contacts, and (g) staying healthy (Winwood et al., 2013). Living real covers components such as emotional regulation and awareness, understanding and sincerity to one's values, and employing personal powers (Winwood et al., 2013). Employees meet the satisfaction and avoid stress when their job aligns with their strengths and values.

Resilience is beneficial for employees as resilient employees would speedily adjust themselves to 
unforeseeable situations and keep working effectively even under unfavourable circumstances (Fredrickson, Tugade, Waugh, \& Larkin, 2003). Efficacy delivered by resilient employees would eventually lead them to gain intensified degrees of work engagement (Cooke, Cooper, Bartram, Wang, \& Mei, 2016). Consequently, organisations could consider employee resilience to be an important resource in supporting work engagement.

Resilient individuals express many favourable attributes such as energy performance, optimism (Block \& Kremen, 1996), and curiosity about new experiences (Waugh, Fredrickson, \& Taylor, 2008). As a result, dynamic and confident employees face challenges with higher readiness at the workplace, which eventually promote work engagement. Research also shows that resilient workers can gain social support at work and establish quality relationships (Fredrickson et al., 2003). The feeling of socially supported and purposeful relationships positively affects work engagement (Christian, Garza, \& Slaughter, 2011). Therefore, resilient employees build meaningful value in their work relationships, endure adversity, and think positive toward life perspectives that may increase work engagement levels.

Employees who perceive their workplace as resourceful and favourable are resilient ones who could reach work engagement (Llorens, Schaufeli, Bakker, \& Salanova, 2007. Based on the conservation of resource theory, Karatepe and Olugbade (2009) also found that employees with robust self-assurance become more fascinated in their daily tasks. Specifically, energetic employees are truly involved and enchanted in their work responsibilities. Bakker, Gierveld, and Van Rijswijk (2006) show that resilience generates engagement among school principals in primary teaching by contributing to the motivational process. Moreover, Waddell (2015) examined how resilience connected with work engagement among nurses and discovered that hope and positive emotions facilitate purposeful behaviour, affecting work engagement.

\section{Theoretical Framework}

The Job Demands- Resources model (JD-R) (introduced by Demerouti, Bakker, Nachreiner, \& Schaufeli, 2001) has been widely utilised in studies related to work engagement. The Oldenburg Burnout Inventory (OLBI) model evaluates disengagement and exhaustion to focus on burnout (Demerouti, Bakker, De Jonge, Janssen, \& Schaufeli, 2001). The model denoted essential entities that shortages of resources played a part in disengagement, whereas excessive demands contributed to exhaustion. Application of the model broadened with the Utrecht Work Engagement Scale (UWES) development removing the negatively worded disengagement subscale of the OLBI to become a positive measure of work engagement.
The JD-R model covers interplays between demands and resources. JD-R assists mitigating roles such as avoiding excess by influencing the correlation between exhaustion and demands (Karasek \& Theorell, 1990). Aligned buffering effects occur through other resources, such as performance feedback and social support (Xanthopoulou, Bakker, Demerouti, \& Schaufeli, 2007). The JD-R model has enlarged to involve job and personal resources as supporters to work engagement. The model portrays job and personal resources as reciprocally elevating. Personal resources comprise self-control and toughness. These resources support employees' prospects for experiencing engagement and refine their capacity to affect available job resources.

The author uses this JD-R model to add to the existing literature. Hence, the author proposed a hypothesis that servant leadership and resilience contribute positively to work engagement among the study sample.

\section{Materials \& Methods}

This research has been approved by the Head of Research in the Faculty of Psychology Universitas Pancasila. The study is quantitative and non-experimental in nature. Participants in this study were female and male permanent employees working in various banks in several cities across Indonesia. They must have worked for a minimum of 1-year tenure to be qualified to participate in this research. An online questionnaire was distributed using a non-probability sampling technique of snowball sampling (aka chain referral sampling). The author first identified and contacted potential subjects in the personal network who were bank employees and provided information about the project and the questionnaire. The author then asked those subjects to recruit other participants in their network and so forth.

Recruitment of participants has followed the ethical considerations. Participant's privacy was respected, and participation was voluntary. The informed consent process clarified that agreeing to contact others was not a requisite for participating in the research. Participants had the option of leaving the online questionnaire at any point. Participants were not pressured to recruit other subjects. While subjects either work in the bank or have worked in the bank, they were not pressured to recruit other subjects or distribute the link to the questionnaire.

The link to the questionnaire was distributed amongst subjects at the time of recruiting. People are eligible to participate as long as they are full-time and has become permanent employees for a minimum of one year in any bank in Indonesia. The author put some screening questions to filter participants based on the requirements. Participants entered a random draw to receive ten shopping vouchers as a reward. The author selected 87 questionnaires for the final analysis after reviewing the quality of received ones. 
In this study, servant leadership and resilience act as independent variables and work engagement as the dependent variable. This study utilised three scales to collect data: 9-item Utrecht Work Engagement Scale (UWES) (Schaufeli \& Bakker, 2004), 6-item Servant Leadership Behaviour Scale (SLBS) (Sendjaya et al., 2017), and 21-item Resilience at Work Scale (RWS) (Winwood, Colon, \& McEwen, 2013). Two different experts in organisational psychology helped the translation and back-translation process. Participants were instructed to give respond to the provided scales.

UWES and RWS assessed participants' attitudes toward themselves, whereas SLBS assessed participants' perceptions of their immediate supervisor. UWES was scored on a seven-point Likert scale, ranging from 0 (never) to 6 (always). Example of UWES item is " $D i$ tempat kerja, saya merasa penuh dengan energi" (At my work, I feel bursting with energy). SLBS was scored on a five-point Likert type scale ranging from 1 (strongly disagree) to 5 (strongly agree). Example of SLBS item is "Atasan saya meningkatkan kapasitas moral pribadi saya" (My supervisor enhances my capacity for moral actions). RWS was scored on a seven-point Likert type scale ranging from 0 (strongly disagree) to 6 (strongly agree). Example of RWS item is "Saya tahu kelebihankelebihan diri saya dan saya menggunakannya secara teratur dalam pekerjaan" (I know my personal strengths and I use them regularly in my work).

The author managed professional judgement to evaluate scales' content. Alpha-Cronbach formulation was used next to determine the instrument's reliability on a pilot study counting in 30 respondents. Reliability coefficient of UWES, SLBS, and RWS are .913, .915, and .924 , respectively. The author also conducted a validity examination by looking at the corrected-item total correlation score. Items in UWES are ranging from .395 to .871 . Items in SLBS are ranging from .638 to .768 . Items in RWS are ranging from .326 to .915 . Zero items had to be dropped from all instruments. Data was then analysed using the technique of multiple linear regression followed by the stepwise method.

\section{Results}

Based on demographic data in Table 1, the sample of 87 employees working in various Indonesian banks consists of $60 \%$ female and $40 \%$ malewho were mostly 31-35 years old (50\%). Moreover, the majority of respondents were staff $(65 \%)$, work in the business department (59\%), have worked for 6-10 years (40\%), and hold a bachelor degree (75\%).
Table 1 Demographic Data

\begin{tabular}{|c|c|}
\hline Variable & $\%$ \\
\hline \multicolumn{2}{|l|}{ Age } \\
\hline $25-30$ & 33 \\
\hline $31-35$ & 50 \\
\hline $36-40$ & 17 \\
\hline \multicolumn{2}{|l|}{ Gender } \\
\hline Male & 40 \\
\hline Female & 60 \\
\hline \multicolumn{2}{|l|}{ Job level } \\
\hline Staff / senior staff & 65 \\
\hline Supervisor / senior spv & 21 \\
\hline Manager & 14 \\
\hline \multicolumn{2}{|l|}{ Department } \\
\hline Business & 59 \\
\hline Operation & 41 \\
\hline \multicolumn{2}{|l|}{ Tenure } \\
\hline $1-5$ years & 36 \\
\hline $6-10$ years & 40 \\
\hline $11-15$ years & 21 \\
\hline $16-20$ years & 3 \\
\hline \multicolumn{2}{|l|}{ Educational degree } \\
\hline Diploma & 16 \\
\hline Bachelor & 75 \\
\hline Master & 9 \\
\hline
\end{tabular}

Participants' scores in all variables are presented in table 2 .

Table 2 Participants' scores

\begin{tabular}{|c|c|c|c|c|}
\hline & $\mathrm{Xmax}$ & $\underline{X \min }$ & Mean & $\underline{\mathrm{SD}}$ \\
\hline Work engagement & 54 & 33 & 46.57 & 6.29 \\
\hline Servant leadership & 30 & 19 & 25.31 & 3.52 \\
\hline Resilience & 116 & 64 & 97.02 & 14.84 \\
\hline
\end{tabular}

Multiple regression testing result shows correlation coefficient number of $\mathrm{r}_{\mathrm{xy}}=.510\left(\mathrm{R}^{2}=.260\right)$ with significance $\mathrm{p}=.000(\mathrm{p}<.05)$. A positive mark in the correlation coefficient shows that the higher supervisor's servant leadership and employee resilience level could intensify the employee's work engagement. Therefore, there is sufficient evidence to suggest that servant leadership and resilience positively affect working engagement. However, this research did not control their effect statistically.

Next, the author executed the stepwise method to determine which independent variable has a stronger effect on the dependent variable. Results showed that servant leadership $(\beta=.484)$ has a bigger effect than resilience $(\beta=.047)$ in predicting work engagement. Moreover, servant leadership $\left(\mathrm{R}^{2}=.258\right)$ has bigger partial contribution than resilience $\left(\mathrm{R}^{2}=\right.$ .089) toward work engagement. If we look further, the 
contribution given by resilience is minimal compared to the whole contribution given by two independent variables.

\section{Discussion}

It is hypothesised that servant leadership and resilience have a positive effect on working engagement. These two independent variables together contribute positively to work engagement. However, when analysed separately, servant leadership has a bigger contribution to work engagement. It implies that the existence of a servant leader would be more beneficial than resilience to employee's work engagement. The author would like to offer some arguments to address this matter.

First, the author would like to argue about the importance of servant leadership. Immediate supervisors represent organisations. They may indeed influence employees because they assign daily commands and feedback to subordinates (Kottke \& Pelletier, 2013). By using the JD-R point of view, capable and nurturing leaders would be able to lead employees with adequate personal and social resources. The subordinates will have elevated self-esteem and a positive internal assessment if they believe that their action is morally and ethically correct (Chen et al., 2015), which are job resources that can promote work engagement (Xanthopoulou et al., 2009). Specifically, in collectivist cultures such as Indonesia, employees' ideal leaders are those who are supportive, paternalistic, and authoritarian (Hanges, Aiken, Park, \& Su, 2016; Purba, Oostrom, Van Der Molen, \& Born, 2015).

Second, resilience may be less important for work engagement. Together with resilience as resources, Derbis \& Jasiński (2018) attempted to examine the relationships between work engagement, job satisfaction, and sense of coherence. The results showed that job satisfaction and sense of coherence supported greater contribution than resilience for work engagement. In the relationship between job satisfaction and work engagement, resilience played a weaker mediating role than a sense of coherence.

The author encountered some limitations during the research stages. First, the study sample represents a small number $(\mathrm{n}=87)$ compared to the total exact population. Participants came from different companies thus are heterogeneous. This condition may lead to less accuracy in result generalisation. As a consequence, this result can only be generalised among the study sample. Second, the self-administered and cross-sectional nature of this study is still potential to bias. Common method variance (CMV) may affect the results. Regardless of the above limitations, this study sheds light on the importance of a leader's servant qualities to complement employees' resilience to foster work engagement.

\section{Conclusion}

This study aimed to add the existing literature by examining job and personal resources to predict work engagement. The author attempted to answer the research question by employing a cross-sectional quantitative approach. Perceived supervisor's servant leadership and individual workplace resilience were examined to find their role in work engagement. It is concluded that both servant leadership and resilience positively affect work engagement among the study sample. However, servant leadership has a bigger partial contribution than resilience toward work engagement. Moreover, the contribution given by resilience is minimal compared to the whole contribution given by two predictors. Finally, this study reveals that a supervisor's servant leadership is an important factor to complement employees' resilience in gaining work engagement.

As a practical recommendation, customised training for department leaders may be organised by Indonesian bank management. The training program objective is to introduce and craft leaders' servant behaviours.

In terms of future research directions, it is recommended to target a larger sample to improve generalisation. It is also recommended to use multiple organisations and probability sampling techniques instead of the snowball sampling technique with larger sample size. Also, organisational studies may benefit from gathering longitudinal data (Podsakoff et al., 2003). 


\section{References}

Arnetz, B. B., Nevedal, D. C., Lumley, M. A., Backman, L., \& Lublin, A. (2009). Trauma resilience training for police: Psychophysiological and performance effects. Journal of Police and Criminal Psychology, 4(1), 1-9. https://doi.org/10.1007/s11896008-9030-y

Bakker, A. B., Demerouti, E., \& Sanz-Vergel, A. I. (2014). Burnout and work engagement: The JD- R approach<https://doi.org/10.1146/annurev-orgpsych031413-091235>. Annual Review of Organizational Psychology and Organizational Behavior, 1, 389-411.

Bailey, C., Madden, A., Alfes, K., \& Fletcher,

L. (2017). The meaning, antecedents, and outcomes of employee engagement: A narrative synthesis.

International Journal of Management Reviews, 19, 3153. https://doi.org/10.1111/ijmr.12077

Bakker, A.B \& Albrecht, S. (2018). Work engagement: current trends. Career Development International, 23(1), 4-11, https://doi.org/10.1108/CDI11-2017-0207

Bakker, A. B., Gierveld, J. H., \& Van Rijswijk, K. (2006). Success factors among female school principals in primary teaching: A study on burnout, work engagement, and performance. Diemen: Right Management Consultants.

Bakker, A. B. (2011). An evidence-based model of work engagement. Current Directions in Psychological Science, 20(4), 265-269.

https://doi.org/10.1177/0963721411414534

Bakker, A. B., Demerouti, E., \& Sanz-Vergel, A. I. (2014). Burnout and Work Engagement: The JD-R Approach (SSRN Scholarly Paper No. ID 2414420) https://doi.org/10.1146/annurevorgpsych-031413-091235 Bardoel, E. A., Pettit, T. M., De Cieri, H., \& McMillan, L. (2014). Employee resilience: An emerging challenge for HRM. Asia Pacific Journal of Human Resources, 52(3), 279-297.

https://doi.org/10.1111/1744-7941.12033

Block, J., \& Kremen, A. M. (1996). IQ and ego resiliency: Conceptual and empirical connections and separateness. Journal of Personality and Social Psychology, 70, 349-361.

https://doi.org/10.1037/0022-3514.70.2.349

Bonanno, G. A. (2004). Loss, trauma, and human resilience: Have we underestimated thehuman capacity to thrive after extremely aversive events? American Psychologist, 59(1), 20-28.

https://doi.org/10.1037/0003-066X.59.1.20

Broyles, L. C. (2005). Resilience: Its relationship to forgiveness in older adults (Doctoral dissertation). Retrieved from ProQuest Dissertations \& Theses Global. (UMI No. 3177245)

Carroll, B. B., \& Patterson, K. (2014). Servant leadership: A cross cultural study between India and the United States. Servant Leadership: Theory and practice, 1(1), 16-45.

Chen, Z., Zhou, J. and Zhu, M. (2015), "How does a servant leader fuel the service fire? A multilevel model of servant leadership, individual self identity, group competition climate, and customer service performance", Journal of Applied Psychology, (100) No. 2, pp. 511-521 https://doi.org/10.1037/a0038036

Christian, M. S., Garza, A. S., \& Slaughter, J. E. (2011). Work engagement: A quantitative review and test of its relations with task and contextual performance. Personnel Psychology, 64(1), 89-136.

https://doi.org/10.1111/j.1744-6570.2010.01203.x Chiniara, M., \& Bentein, K. (2016). Linking servant leadership to individual performance: Differentiating the mediating role of autonomy, competence and relatedness need satisfaction. The Leadership Quarterly, 27, 124-141. https://doi.org/cbsr Cooke, F. L., Cooper, B., Bartram, T., Wang, J., \& Mei, H. (2016). Mapping the relationships between high-performance work systems, employee resilience and engagement: A study of the banking industry in China.

The International Journal of Human Resource

Management, 1-22,

https://doi:10.1080/09585192.2015.1137618

Demerouti, E., Bakker, A. B., De Jonge, J., Janssen, P. P., \& Schaufeli, W. B. (2001). Burnout and engagement at work as a function of demands and control Scandinavian Journal of Work, Environment \& Health, 27, 279-286. https://doi.org/10.5271/sjweh.615

Demerouti, E., Bakker, A. B., Nachreiner, F., $\&$ Schaufeli, W. B. (2001). The job demands- resources model of burnout Journal of Applied Psychology, 86(3), 499. https://doi/10.1037/0021-9010.86.3.499

Derbis, R. \& Jasiński, A.M. (2018). Work satisfaction, psychological resiliency and sense of coherence as correlates of work engagement. Cogent Psychology, 5, 1-16,

https://doi.org/10.1080/23311908.2018.1451610

Eva, N., Robin, M., Sendjaya, S., van Dierendonck, D., \& Liden, R. C. (2019). Servant leadership: A systematic review and call for future research - The leadership quarterly yearly review for 2019. The Leadership Quarterly, 30(1), 111-132. https://doi.org/10.1016/j.leaqua.2018.07.004

Fredrickson, B. L., Tugade, M. M., Waugh, C. E., \& Larkin, G. R. (2003). What good are positive emotions in crisis? A prospective study of resilience and emotions following the terrorist attacks on the United States on September 11th, 2001. Journal of Personality and Social Psychology, 84(2), 365.

https://doi.org/10.1037/0022-3514.84.2.365

Fougere, A., Daffern, M., \& Thomas, S.

(2015). Does resilience predict recidivism in young offenders?. Psychiatry, Psychology and Law, 22(2), 198 212. https://doi.org/10.1080/13218719.2014.936333 Greenleaf, R. K. (1977). Servant leadership. Paulist Press.

Hanges, P. J., Aiken, J. R., Park, J., \& Su, J. (2016). Cross-cultural leadership: Leading around the world. Current Opinion in Psychology, 8(April), 64-69. https://doi.org/10.1016/i.copsyc.2015.10.013

Herrman, H., Stewart, D. E., Diaz-Granados, N., Berger, E. L., Jackson, B., \& Yuen, T. (2011). What is resilience? The Canadian Journal of Psychiatry, 56(5), $258-265$

https://doi.org/10.1177/070674371105600504

Hoch, J. E., Bommer, W. H., Dulebohn, J. H., $\&$ Wu, D. (2018). Do ethical, authentic, and servant leadership explain variance above and beyond transformational leadership? A meta-analysis. Journal of Management, 44(2), 501-529.

https://doi.org/10.1177/0149206316665461

Hoole, C., \& Bonnema, J. (2015). Work engagement and meaningful work across generational cohorts. SA Journal of Human Resource Management, 
13(1), 1-11.

https://doi.org/10.4102/sajhrm.v13i1.681 Hutauruk, D.M. (2020). Peran perbankan sangat besar dalam menggerakkan ekonomi nasional. Retrieved from

https://keuangan.kontan.co.id/news/peran-perbankansangat-besar-dalam-menggerakkan-ekonomi-nasional

Kahn, W. A. (1990). Psychological Conditions of Personal Engagement and Disengagement at Work. Academy of Management Journal, 33(4), 692-724. https://doi.org/10.5465/256287

Kaltiainen, J. \& Hakanen, J. (2020). Fostering task and adaptive performance through employee wellbeing: the role of servant leadership. Business Research Quarterly, 1-16, https://doi:10.1177/2340944420981599

Karasek, R. A., \& Theorell, T. (1990). Healthy work: Stress, productivity and the reconstruction of working life. New York, NY: Basic Books

Karatepe, O. M., \& Olugbade, O. A. (2009).

The effects of job and personal resources on hotel employees' work engagement. International Journal of Hospitality Management, 28(4), 504-512.

https://doi.org/10.1016/j.ijhm.2009.02.003

Kaya, B., \& Karatepe, O. M. (2020). Does servant leadership better explain work engagement, career satisfaction and adaptive performance than authentic leadership? International Journal of Contemporary Hospitality Management, 32(6), 20752095. https://doi.org/10.1108/IJCHM-05-2019-0438

Kottke, J. L., \& Pelletier, K. L. (2013).

Measuring and differentiating perceptions of supervisor and top leader ethics. Journal of Business Ethics, 113(3), 415-428. https://doi.org/10.1007/s10551-012-1312-8

Kuntz, J., Näswall, K. and Malinen, S. (2016),

"Resilient employees in resilient organisations: flourishing beyond adversity", Industrial and Organisational Psychology, 9(2), 456-462. https://doi.org/10.1017/iop.2016.39

Laub, J. (2018). Leveraging the power of servant leadership: Building high performing organisations. Palgrave Macmillian. https://doi.org/10.1007/978-3-319-77143-4

Leiter, M. P., \& Maslach, C. (2003). Areas of worklife: A structured approach to organisational predictors of job burnout. In P. Perrewe \& D. Ganster (Eds.), Emotional and Physiological Processes and Positive Intervention Strategies (3rd ed., pp. 91-134). https://doi.org/10.1016/S1479-3555(03)03003-8

Lichtenthaler, P. W., \& Fischbach, A. (2019). A meta-analysis on promotion- and prevention-focused job crafting. European Journal of Work and Organisational Psychology, 28(1), 30-50. https://doi.org/10.1080/1359432X.2018.1527767 Llorens, S., Schaufeli, W., Bakker, A., \& Salanova, M. (2007). Does a positive gain spiral of resources, efficacy beliefs and engagement exist? Computers in Human Behaviour, 23(1), 825-841. https://doi.org/10.1016/j.chb.2004.11.012

Luthans, F. (2002). The need for and meaning of positive organisational behaviour. Journal of Organisational Behaviour, 23, 695-706. https://doi.org/10.1002/job.165

McLarnon, M. J., \& Rothstein, M. G. (2013). Development and initial validation of the Workplace Resilience Inventory. Journal of Personnel Psychology, 12(2), 63-73. https://doi.org/10.1027/1866- 5888/a000084

Näswall, K., Kuntz, J., Hodliffe, M., \&

Malinen, S. (2013, December). Employee resilience scale (EmpRes): Technical report. (Resilient Organisations Research Report 2013/06). Retrieved from https://ir.canterbury.ac.nz/handle/10092/9469

Nilakant, V., Walker, B., Kuntz, J., de Vries, H., Malinen, S., Näswall, K. and van Heugten, K. (2016), "Dynamics of organisational response to a disaster: a study of organisations impacted by earthquakes", in Hall, M., Malinen, S., Vosslamber, R. and Wordsworth, R. (Eds), Business and Post-disaster Management: Business, Organisational and Consumer Resilience and the Christchurch Earthquakes, Routledge, Abingdon, pp. 35-47. https://doi.org/10.4324/9781315640211-3

Parris, D.J.W. (2013), “A systematic literature review of servant leadership theory in organisational contexts", Journal of Business Ethics, (113) 3, 377-394. https://doi.org/10.1007/s10551-012-1322-6

Podsakoff, P. M., MacKenzie, S. B., Lee, J. Y., \& Podsakoff, N. P. (2003). Common method biases in behavioural research: A critical review of the literature and recommended remedies. Journal of Applied Psychology, 88(5), 879-903.

https://doi.org/10.1037/0021-9010.88.5.879

Purba, D. E., Oostrom, J. K., Van Der Molen, H. T., \& Born, M. P. (2015). Personality and organisational citizenship behaviour in Indonesia: The mediating effect of affective commitment. Asian Business and Management, 14(2), 147-170. https://doi.org/10.1057/abm.2014.20

Reyes, A. T., Andrusyszyn, M. A., Iwasiw, C., Forchuk, C., \& Babenko-Mould, Y. (2015). Nursing students' understanding and enactment of resilience: A grounded theory study. Journal of Advanced Nursing, 71(11), 2622-2633. https://doi.org/10.1111/jan.12730

Salanova, M., Schaufeli, W. B., Llorens, S., Peiro, J. M., \& Grau, R. (2000). Desde el "burnout" al "engagement": ¿una nueva perspectiva? Revista de Psicología Del Trabajo y de Las Organizaciones, 16(2), 117-134.

Samuels, S. L. (2015). Resilience among immigrant adult learners: Experiences in postsecondary education--A mixed-methods study (Doctoral dissertation). Retrieved from ProQuest Dissertations \& Theses Global. (UMI No. 3688883)

Schaufeli, W. B. \& Bakker, A. B. (2004).

Utrecht Work Engagement Scale: Preliminary manual. Utrecht University: Occupational Health Psychology Unit.

Saria, M. G., Courchesne, N., Evangelista, L., Carter, J., MacManus, D. A., Gorman, M. K., \& Maliski, S. (2017). Cognitive dysfunction in patients with brain metastases: Influences on caregiver resilience and coping. Supportive Care in Cancer, 25(4), 1247-1256. https://doi.org/10.1007/s00520-016-3517-3

Robertson, I.T., Cooper, C.L., Sarkar, M. and Curran, T. (2015), "Resilience training in the workplace from 2003 to 2014: a systematic review", Journal of Occupational and Organisational Psychology, 88(3), 533-562. https://doi.org/10.1111/joop. 12120

Russell, R. F. (2001). The role of values in servant leadership. Leadership \& Organisation Development Journal, 22(2), 76-84. https://doi.org/10.1108/01437730110382631 
Schaufeli, W. B., Bakker, A. B., \& Salanova, M. (2006). The measurement of work engagement with a short questionnaire: A cross-national study. Educational and Psychological Measurement, 66(4), 701-716.

Sendjaya, S., Eva, N., Butar Butar, I., Robin, M., \& Castles, S. (2017). SLBS-6: Validation of a short form of the Servant Leadership Behaviour Scale. Journal of Business Ethics, https://doi.org/10.1007/s10551-017$\underline{3594-3}$

Spears, L. C. (1995). Introduction: Servantleadership and the Greenleaf legacy. In L. C. Spears (Ed.) Reflections on leadership: How Robert K. Greenleaf's theory of servant-leadership influenced today's top management thinkers. New York, NY: John Wiley.

https://doi.org/10.1108/01437739610148367

Southwick, S., Bonnano, G., Masten, A., Panter-Brick and Yehuda, R. (2014), "Resilience definitions, theory and challenges: Interdisciplinary perspectives", European Journal of Psychotraumatology 5(1), 1-14. https://doi.org/10.3402/ejpt.v5.25338

Sokoll, S. (2014). Servant leadership and employee commitment to a supervisor. International Journal of Leadership Studies, 8(2), 88-104. ISSN 1554 $-3145$

van Dierendonck, D. (2011). Servant leadership: A review and synthesis. Journal of Management, 37(4), 1228-1261.

https://doi.org/10.1177/0149206310380462

Waddell, W. J. (2015). Resilience and engagement in mental health nurses (Doctoral dissertation). Capella University.

Waugh, C. E., Fredrickson, B. L., \& Taylor, S. F. (2008). Adapting to life's slings and arrows: Individual differences in resilience when recovering from an anticipated threat. Journal of Research in Personality, 42(4), 1031-1046.

https://doi.org/10.1016/i.jrp.2008.02.005

Williams, G. (2017). Resisting burnout: Correctional staff spirituality and resilience. (Doctoral dissertation). Retrieved from ProQuest Dissertations \& Theses Global. (UMI No. 10272384).

Winwood, P.C., Colon, R., \& McEwen, Kath. (2013). A practical measure of workplace resilience: Developing Resilience at Work Scale. Journal of Occupational \& Environmental Medicine, 55(10). https://doi.org/10.1097/JOM.0b013e3182a2a60a

Xanthopoulou, D., Bakker, A. B., Demerouti, E., \& Schaufeli, W. B. (2007). The role of personal resources in the job demands-resources model. International Journal of Stress Management, 14(2), 121141. https://doi.org/10.1037/1072-5245.14.2.121

Xanthopoulou, D., Bakker, A.B., Demerouti, E. and Schaufeli, W.B. (2009), "Work engagement and financial returns: a diary study on the role of job and personal resources", Journal of Occupational and Organisational Psychology, 82(1), 183-200. https://doi.org/10.1348/096317908X285633

Yu, N. X., Liu, C., \& Yue, Z. (2017).

Resilience mediated the association between acculturation and psychological growth in college students from Hong Kong to Guangzhou, China. Journal of Mental Health, 26(4), 326-333. https://doi.org/10.1080/09638237.2017.1294730 